\title{
Influence of Conditional Cash Transfer on Household Economic Outcomes: Perspective of Livelihood Empowerment Against Poverty (LEAP) Beneficiaries in Builsa North District of Ghana
}

\author{
Paul Akanvariwen Asianab* Frank K. Teng-Zeng \\ 1.Faculty of Agribusiness and Applied Economics, University for Development Studies P.O. Box 1350. Tamale. \\ Ghana \\ 2.Faculty of Integrated Development Studies, University for Development Studies Wa Campus P.O. Box 520. \\ Wa. Ghana
}

\begin{abstract}
Abject poverty remains widespread in many parts of the world today despite the remarkable progress achieved since the Second World War. Though poverty levels in Ghana have declined in terms of hard-core poor, the decline in poverty has, however, not been geographically spread equally. Achieving poverty reduction goals in Ghana, the Livelihood Empowerment Against Poverty (LEAP) Social Grants scheme was introduced as an effective longterm response to extreme poverty among vulnerable groups. This study assessed the influence of LEAP Cash Transfer on the economic outcomes of beneficiaries in the Builsa North District of Upper East Region, Ghana. The study employed a case study design. Data was collected from 156 randomly selected respondents using qualitative questionnaires, and focused group discussions. The study found that LEAP has played a pivotal role at strengthening the economic and social fortunes of majority of vulnerable households. It has enhanced households' ability to participate in social functions, access education/literacy as human capital asset, and access vast agricultural lands to undertake crop farming activities. The study recommends to the implementing ministry, the Ministry of Gender and its subsidiary agencies at the District level to educated beneficiaries of the CCT to believe more in their individual efforts with little support such as the cash transfer.

Keywords: Conditional Cash Transfer, Household Economic Outcome, LEAP, Builsa North, Livelihood framework

DOI: $10.7176 /$ RHSS/10-14-04

Publication date:July $31^{\text {st }} 2020$

\section{Introduction}

Abject poverty remains widespread in many parts of the world today despite the remarkable progress achieved since the Second World War. According to the World Bank's much cited "dollar-a-day" international poverty line, which was revised in 2008 to $\$ 1.25$ a day in 2005 prices, there are still 1.4 billion people living in poverty (FAO, 2009). The Global Multidimensional Poverty Index (MPI) which was developed in 2010 by Oxford Poverty and Human Development Initiative (OPHI) and the United Nations Development Programme's (UNDP's) annual flagship Human Development Reports, measure poverty by its incidence and intensity, and estimates that about 1.6 billion people in the world are living in multidimensional poverty (Alkire et al, 2014). Almost all the hungry people, 791 million, live in developing countries, representing 13.5 percent, or one in eight, of the population of developing counties. There are 11 million people undernourished in developed countries (FAO, 2014).

The incidence of poverty is high on the African continent that governments and well-meaning people are putting in efforts to alleviate poverty and enhance food security. As a result, the prevalence of undernourishment in sub-Saharan Africa has declined from 33.3 percent in 1990- 92 to 23.8 percent in 2012-14, although the number of undernourished people has actually increased (FAO, 2014). Between 1980 and 2005, poverty rate in Sub Saharan Africa had consistently hovered above 50 percent. Given the continent's high population growth, its number of poor rose steadily. In 2005, the rate was $54.5 \%$ and in 2010 it was around $46.9 \%$. The total number of poor people in the region is falling too, albeit slowly. Better still, by 2015 , the poverty rate is expected to fall below 40 percent (Chandy and Gertz, 2011). These efforts however seem not to be far reaching and poverty seem to be taking new dimensions every now and then.
\end{abstract}

\subsection{State of Poverty in Ghana}

In Ghana, it is obvious, that people within this poverty bracket often lack the very basics of life like access to health care, decent food, clean water, clothes and shelter. For instance, 18.2 percent of Ghanaians live in extreme poverty (Adjei et al., 2012; Ghana Statistical Service, 2008) and do not have adequate resources to meet their basic food requirements (Jones et al., 2009). The Ghana National Social Protection Strategy (NSPS) document showed that more than $40 \%$ of Ghanaian are "poor", thus referring to citizens who have the capacity to meet their basic nutritional needs, but are unable to cater for additional necessities such as health, shelter, clothing and education. Ghana's poverty level has declined to about 24.2 percent from the 51 percent recorded in 1991 (GoG, 2007). 
Though poverty levels in Ghana have declined in terms of hard-core poor, the decline in poverty has, however, not been equally spread geographically (CCEIR-UDS, 2011). Northern Ghana lags behind the rest of the country in almost all development indicators. Six out of ten people are poor, compared to just two out of ten in the southern section. A 2012 Comprehensive Food Security and Vulnerability Analysis identified poverty as the leading cause of food insecurity in Northern Ghana (WFP, 2013). The three regions of northern Ghana have the highest MPI poverty incidence: Northern Region (80.9\%), Upper East Region (80.8\%) and Upper West Region (77.6\%). The positions of the three northern regions on the MPI ranking are broadly in line with the Ghana Statistical Service poverty measurement which recorded poverty incidence in 2006 of 52.3 percent for the Northern Region, Upper East Region (70.4\%) and Upper West Region (87.9\%) - far higher than the national average of 28.5 percent. Interestingly, while the MPI poverty incidence appears to be extremely high for all the three regions of the northern, the average intensity of deprivation between these regions and the rest of the regions of Ghana is marginal or not significant (GSS, 2013).

To live a life free from poverty and hunger is one of the human rights and fundamental freedoms enshrined in the Universal Declaration of Human Rights. Article 25 (1) of the Declaration states that "Everyone has the right to a standard of living adequate for the health and well-being of himself and of his family, including food, clothing, housing and medical care and necessary social services". This right is further reaffirmed in the International Covenant on Economic, Social and Cultural Rights and the International Covenant on Civil and Political Rights.

As part of the major strives to respond to these declarations and reduce poverty, developed and developing countries all over the world have instituted social protection schemes as social support systems to ensure that everyone should have a minimal standard of living, and that people living in poverty should receive assistance when they lack the means to live lives that affirm their human worth and dignity. To this end, social protection is now an emerging concept in the contemporary world which has been adopted by nations in the interest of social justice (Kumado and Gockel, 2003).

Consequentially, Ghana developed the National Social Protection Strategy (NSPS) which represents the country's vision of creating an all-inclusive society through the provision of sustainable mechanisms for the protection of persons living in situations of extreme poverty, vulnerability and exclusion. The NSPS is founded on the principle that every Ghanaian matter and is capable of contributing his or her quota to national development (GoG, 2007). The NSPS supports the county's vision of becoming middle income country by 2015 by empowering extremely poor citizens to contribute to and share in the benefits of socio-economic growth by freeing them from the malaise of under development. Achieving the poverty reduction goals of the NSPS, the Livelihood Empowerment Against Poverty (LEAP) Social Grants scheme was introduced to provide target groups with a reliable and cost-effective cash transfer to support their basic human needs. Under the LEAP, cash income is provided as a form of social assistance, which is increasingly becoming a major part of anti-poverty policy measures in most countries (DFID, 2011). In this regard, Ghana embraced cash transfer as an effective long-term response to extreme poverty eradication among vulnerable groups.

This paper sought to establish whether the cash transfer, as an anti-poverty policy measure has strengthened household economic security, reduce risks and shocks and improve livelihood choices in the Builsa North District which has been described as a 'poverty trap' by Professor Jeffrey Sacchs (CEPA, 2004). Specifically, the paper seeks to determine the effect of small but predictable flow of cash income on household economic assets in the district, and the extent to which the provision of cash income has influenced the household economic outcomes. The rationale is also to ascertain whether the resources (inputs) invested in the economic activity (i.e. agriculture and trade related activities) by the cash transfer produced the expected level of output (i.e. economic outcomes) and benefit, and contributed to fulfilling the objective the cash transfer program.

The rest of the paper is structured as follows: section 2 covers the theoretical overview of conditional cash transfer and its operation in different countries and the Ghanaian context, as well as the study guiding conceptual framework. Section 3 deals with the study area and the methods and, while section 4 presents the results and discussions, finally section 5 draws conclusion.

\section{Conditional Cash Transfer: A Theoretical Overview 2.1. Cash transfer programs}

Cash transfer programs are social assistance programs that provide cash incomes to poor households provided they make certain investments in human capital, normally the recipient's children. Cash Transfers are generally targeted at education, health, and malnutrition in youth, often providing money to parents who send their children to school or have them get regular doctors' visits- typically both (Abelsohn, 2011). Most Conditional Cash Transfer (CCT) programs transfer the money to the mother of the household or to the student in some circumstances (Fieszben et al., 2009). CCT programs have two clear objectives. First, to provide poor households with a minimum consumption floor, and second to encourage the accumulation of human capital and to break a vicious cycle whereby poverty is transmitted across generations.

Countries have been adopting or considering adoption of CCT programs at a prodigious rate. Virtually every 
country in Latin America has such a program. CCTs have been hailed as a way of reducing inequality, especially in the very unequal countries in Latin America and Asia by helping households break out of a vicious cycle whereby poverty; promoting child health, nutrition, and schooling; and helping countries meet the Millennium Development Goals (Fieszben et al., 2009). In different parts of the world, cash transfer systems have evolved differently because there are variations between the well-established and complex social protection systems that exist in Europe and North America (Schubert \& Slater, 2006). The principal objective of cash transfers is to facilitate household consumption of basic needs to the elderly, the disabled and widows as well as human immunodeficiency virus (HIV) and acquired immune deficiency syndrome (AIDS) orphans (Case \& Deaton, 1998; Farrington, Slater \& Holmes, 2004) and other livelihood support payments to households living below the poverty line (Slater, 2011).

One of the earliest and largest scale cash transfer programs is the Mexican Oportunidades program (formerly called PROGRESA), in which 30 million people are currently participating. Cash benefits are linked both to regular school attendance of children and to regular clinic visits by beneficiary families. Average household benefits amount to about US\$35-40 monthly. The Oportunidades program was first initiated in 1997 in rural areas of Mexico (Behrman, Gallardo-Garcia, Parker, Todd, \& Velez-Grajales, 2012). Brazil also is exemplary in its use of CCTs. It started early, its programs have evolved enormously, and the current program (Bolsa Família) launched in 2003 is similar to Mexico's program in coverage and importance. In various respects, Brazil's Bolsa Família program provides something of an interesting contrast to the Mexican case- the issue of federalism is more in the forefront; it takes a softer, more gradual tack on conditions; and puts a shade more emphasis on redistribution than on human capital formation (Fieszben et al., 2009).

In Ghana cash transfer was implemented under the Livelihood Empowerment Against Poverty (LEAP) Program to, as part of its mandate, address chronic poverty and vulnerability. The program was first piloted in 2008 with 1,654 beneficiary households in 21 districts, began expanding in 2009 and 2010, reached 68,000 households in 2012 and is expected to increase to 165,000 households across Ghana by 2015 (Daily Graphic, 2012). LEAP is a program that aims at supplementing the incomes of dangerously poor households through the provision of cash transfers and linking them up with complementary services so that over time, they can leap out of poverty (Gbedemah, Jones \& Pereznieto, 2010; National Social Protection Strategy, NSPS, 2007). LEAP combines both conditional and unconditional cash transfers and eligibility is based on poverty and having a household member in at least one of three demographic categories; single parent with orphan or vulnerable child, elderly poor, or person with extreme disability unable to work (PWD). Under the LEAP, the categories of beneficiaries identified as the most vulnerable in society are: caregivers of orphans and vulnerable children (OVC); pregnant and lactating women; impoverished elderly; severely disabled persons; and households dependent on fishing and subsistence food crop farming. The LEAP program sets positive conditionalities that promote synergies with complementary social services, which include children's school enrolment and retention, registration at birth, uptake of post-natal care and immunisations for young children (Gbedemah et al., 2010). Additionally, other conditionalities aim at eliminating certain behaviours, such as child trafficking and children engaging in worst forms of child labour.

In many developing countries, social safety net programs are a crucial part of a well-designed development strategy. They aim to manage social risk, increase equity, reduce poverty, and provide social protection. Because of the potential long-term benefits of positive behaviour changes associated with conditionality, Cash Transfer programs could be a vital part of a country's development strategy. International development partners and donor agencies have recognized cash transfer as a core pro-poor development tool for reducing short-term poverty and breaking the intergenerational transmission of poverty, particularly in sub-Saharan African countries (DFID, 2011; Holmes \& Barrientos, 2009). Schubert (2008) opined that poor households most often adopt micro-coping mechanisms, including withdrawing children from school and children taking up informal employment. Also, men and women opt for distress sales and migration and the disable and aged resort to the streets begging and appealing for support. These, among others, reinforce the spiral of poverty. The increased numbers of these unfortunate cases suggest the need for policies and programs that could simultaneously address poverty and vulnerability among households and enable them achieve their full potential. Cash transfer is tagged as a magic bullet in development and perceived as a panacea to escape poverty, promote inclusion and provide the much-needed stimulus to enhance the human capital development (Adato \& Hoddinott, 2010).

This paper recognises a relationship among cash transfer as a transformational structure, a portfolio of economic assets available to the rural household, the external influences, the economic strategy/activity and the economic outcomes (Figure 1). Thus, Conditional Cash Transfer influences household economic assets which are also influenced by certain external factors are used for household economic strategies/activities that generate household economic outcomes. These outcomes can also be used to re-invest in these household economic assets.

\subsection{The Cash transfer program Framework}

a. Transforming Structures 
Transforming Structures within the framework is the cash transfer that has facilitated household access to cash income, health insurance, agricultural inputs micro credit, among others. These affect the assets and opportunities that are available, and their productivity: e.g. government policy, formal organization (farmers' groups, local authority, etc.) and informal institutions, which include societal rules and norms (market networks, credit systems, discrimination and access to markets).

\section{b. Economic Assets}

Economic assets are the basic livelihood building blocks. Poverty analyses have shown that people's ability to escape from poverty is critically dependent on their access to assets (Booth et al., 1998). The framework identifies five core asset categories or types of capital upon which livelihoods are built. These include human, social, natural, physical and financial capital.

\section{c. Economic Strategies}

Economic strategies are used to denote the range and combination of activities and choices that people make or undertake in order to achieve their livelihood goals (including productive activities, investment strategies, reproductive choices, etc.). Poor people usually pursue a diverse portfolio of activities, including on-farm activities, off-farm activities and migration, using their assets.

d. Economic Outcomes

These refer to components of improved wellbeing (e.g. good health, more income, reduced vulnerability, empowerment, food security, etc.). Economic outcomes are the achievements or outputs of livelihood (economic) strategies.

\section{e. External factors}

The external environment in which people exist is part of the framework that lies furthest outside people's control. People's wellbeing and the wider availability of assets are fundamentally affected by critical trends as well as by shocks and seasonality- over which they have limited or no control. Therefore, the conceptual framework of the study in which the cash transfer program is the transforming structure plays an important role in improving the lives of rural poor and vulnerable people in the Builsa North District. From the framework, it will be realised that the transforming structure (i.e. cash transfer) influences household access to the economic assets which are used for the agricultural, agro forestry and other trade related activities to generate the household economic outcomes. From the figure, it will also be realised that apart from the transforming structure (i.e. cash transfer), there are also external factors (e.g. vulnerability context) which influence access to economic assets and outcomes of the household farmers and traders. Therefore, the enhancement or otherwise of the economic assets and outcomes is dependent on both the cash transfer and the external factors.

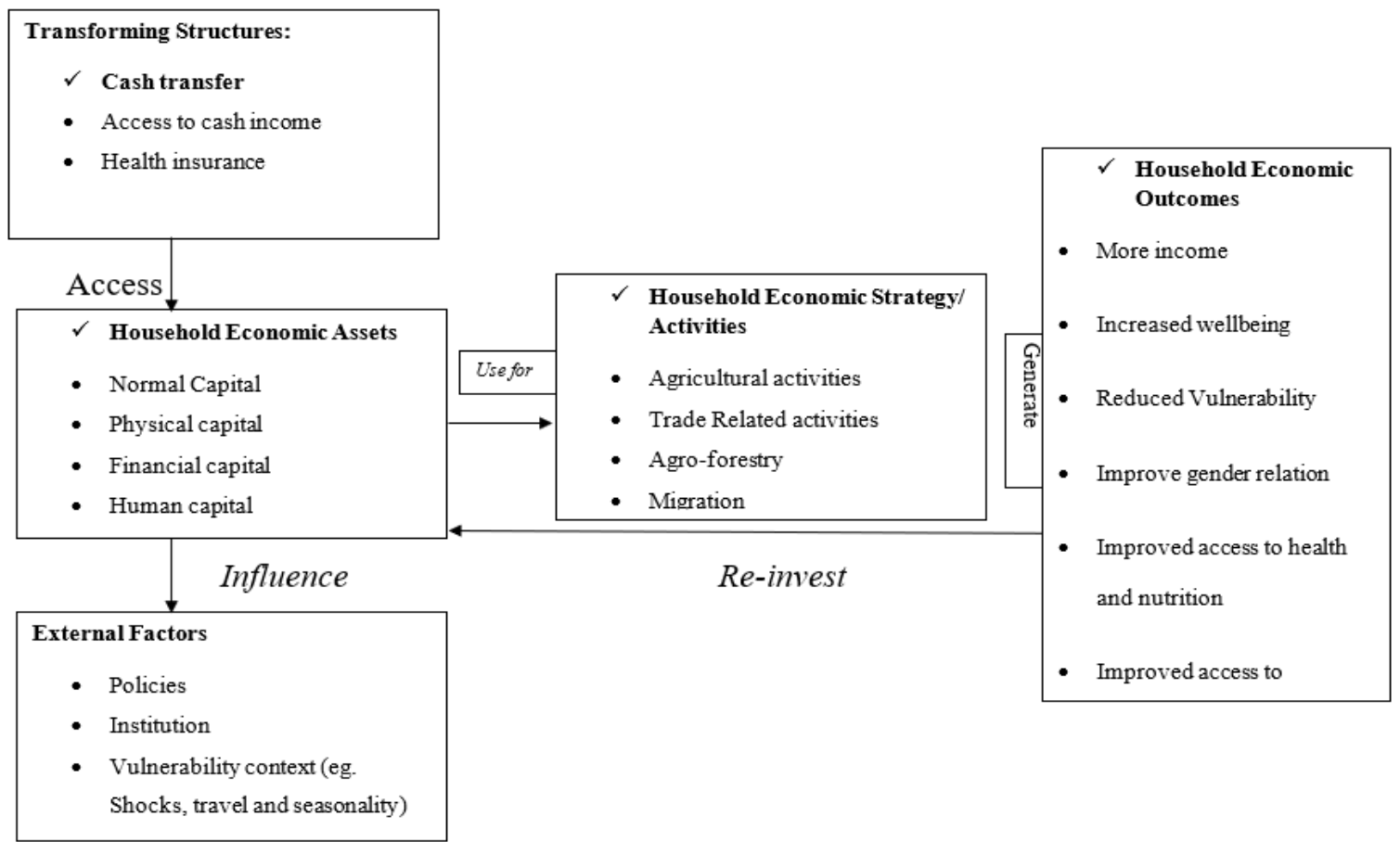

Figure. 1 Conceptual framework

Source: Adapted from DFID (1999) livelihood Guidance sheet.

\section{Methodological Framework}


The Builsa North District is one of the thirteen administrative districts in the Upper East Region of Ghana. The district lies between longitudes $1^{0} 05^{\prime}$ West and $1^{0} 35^{\prime}$ West and latitudes $10^{\circ} 20^{\prime}$. Agricultural, a mainstay economic activity in the district is one of the most vulnerable economic sectors in the district. The district has two major agricultural activities being crop farming (96.3\%) and livestock rearing $(81.4 \%)$ but with low productivity levels attributed to climatic and ecological conditions (GSS, 2014). The low levels of productivity also imply increased vulnerability as the levels of production are close to survival. The dominant shocks affecting incomes, availability of food and wealth accumulation, are those that relate to crop production and livestock (BDM-TDP, 2010). In the District Human Development Report (DHDR) for Atwima, Tema and Builsa (now Builsa North and South) districts, the Builsa District was identified as the district with the highest incidence of poverty at a rate of 98\% (DHDR, 2004). In sum, the district displays such features, described by Professor Jeffrey Sachs as, a 'poverty trap'. Sachs's proposition for addressing the 'poverty trap' is intensive, integrated interventions to tackle a range of development challenges at the same time. LEAP has been in existence in the Builsa North District the programme began.

The study used the mixed method approach in the district. Survey instruments and interview guides were used with the questionnaire and the use of focused group discussions with the LEAP beneficiaries specifically. The Builsa North District was purposively selected because it suffers more with large population at risk compared to the other districts in the region. The district has about 651 registered households out of 23 registered communities from 5 Town/Area Councils, i.e. Chuchuliga, Sandema, Siniensi, Kadema, and Wiaga. Therefore, after purposively selecting the study district, cluster sampling was employed to cluster the study district into 5 zones based on the 5 Town/Area Councils in the district. This technique was also found suitable because the Department of Social Development zoned the LEAP beneficiary communities into 5 zones in the Builsa North district. From the clustered zones, a simple random sampling technique was adopted using the lottery methods to select the zones into 9 communities, 1 from Chuchuliga because of its clustered nature and 2 each from Sandema, Siniensi, Kadema, and Wiaga because of the similarities in the number of communities within each of them.

Stratified sampling was used to stratify each community into beneficiary households and non-beneficiary households. This offered the researcher the opportunity of selecting from each stratum a number of households for the study. Stratification produces a lower standard error because the total variation for any particular variable in a population may be regarded as composed of variation between strata and variation within strata. Stratum should be made as different as possible while maximising the similarity of elements within strata (Osuala, 2007). Further to the sampling process, a simple random was adopted to select 156 respondents based on the sample size, from the strata to collect primary data for the study. The sample size was determined from the formula, $\mathbf{n}=$ sample size, $\mathbf{N}=$ sample frame and $\boldsymbol{\alpha}$ represents the margin of error (e.g. 0.08) with confidence level of (e.g. 92\%).

$$
\mathbf{n}=\mathbf{N} / \mathbf{1}+\mathbf{N}(\boldsymbol{\alpha})^{2}
$$

\subsection{Results and Discussions}

This section presents the findings of selected social characteristics of the study population. The study selected those social characteristics deemed relevant to the objectives of the research; age, sex, and occupation. Data is also presented on the effects of cash transfer on households' economic and financial assets and economic outcomes.

\subsection{Socio-Demographic Characteristics of Respondents}

Age is an important social factor in determining the working ability of any person (Atengdem, 1997). The ages of respondents are presented into four categories as: less than 20 years; 20 to 39 years; 40 to 59 years; and 60 years and above. The study interviewed a total 156 respondents of which $50 \%$ were beneficiaries. It was revealed that about $23 \%$ of the respondents are aged less than 20 years (i.e., 14\% beneficiaries and 19\% non-beneficiaries) and about $30 \%$ are aged 60 years and above (i.e., $16 \%$ beneficiaries and $14 \%$ non-beneficiaries) as shown in Table 1 below.

Table1: Age of respondents

\begin{tabular}{|l|l|l|l|l|l|l|}
\hline \multirow{2}{*}{ Age category } & \multicolumn{2}{|c|}{ All respondents } & \multicolumn{2}{c|}{ Beneficiaries } & \multicolumn{2}{c|}{ Non-beneficiaries } \\
\cline { 2 - 7 } & Frequency & $\begin{array}{l}\text { Percentage } \\
(\%)\end{array}$ & Frequency & $\begin{array}{l}\text { Percentage } \\
(\%)\end{array}$ & Frequency & $\begin{array}{l}\text { Percentage } \\
(\%)\end{array}$ \\
\hline All ages & 156 & 100 & 78 & 50 & 78 & 50 \\
\hline $\begin{array}{l}\text { Less than 20 } \\
\text { years }\end{array}$ & 36 & 23 & 22 & 14 & 14 & 9 \\
\hline 20 to 39 years & 36 & 23 & 13 & 8 & 23 & 15 \\
\hline 40 to 59 & 37 & 24 & 18 & 12 & 19 & 12 \\
\hline 60 and above & 47 & 30 & 25 & 16 & 22 & 14 \\
\hline
\end{tabular}


This is compared to the district figures of about $50.9 \%$ for ages less than 20 years and about $9.4 \%$ of ages 60 years and above and a regional distribution of about $60 \%$ for ages less 20 years and $9.2 \%$ for ages 60 years and above (GSS, 2013). The study reveals a significant variation between the figures from the study and that pertaining to the district and regional figures. The variation could stem from the fact that the cash income given to poor households is dominant with the impoverished aged on one hand and orphans and vulnerable children on the other hand, and could have accounted for the higher figures in the study. Conventionally, there is a widespread observation that the age of a person wields greater influence on his/her disposition and indeed capable of ordering his or her economic activities. Under the cash transfer programme, the categories of beneficiaries identified as the most vulnerable in society included vulnerable children (OVC) and impoverished (Gbedemah et al., 2010). Thus, a total of about $30 \%$ of beneficiary respondents, (i.e. 14\% less than 20 years and $16 \%$ aged 60years and above), from the study directly benefit as the aged and OVC. The beneficiary aged brackets 20 to 39 and 40 to 59 years, were mostly care-givers and the disable, and account for $20 \%$ of beneficiary respondents. This implies that they are able to access some economic assets which could enable them undertake some economic activities, such as farming and trading, hence more income and reduced vulnerability. However, the study also revealed that about $23 \%$ of non-beneficiaries are within the vulnerable aged brackets of less than 20 years and above 60 years and will require some form of support especially the cash transfer to meet household needs since the study found out that most of them are vulnerable. As compared to beneficiaries in the same age brackets, it implies that most of the aged and OVC are benefiting from the cash income and could be in a better position to provide for household needs than non-beneficiaries.

Across the globe, the gender of people greatly influences their chances of benefiting from a cash transfer. Schady and Rosero (2007) contend that cash payments to women significantly increase the proportion of household expenditure that go to food. Female recipients save larger fraction of the transfers, though this difference is not statistically significant (Dufla, 2003). Majority (57\%) of the respondents were females with $43 \%$ males. This is compared to the district figure of $49.21 \%$ for males and $50.79 \%$ for females (Figure 2).

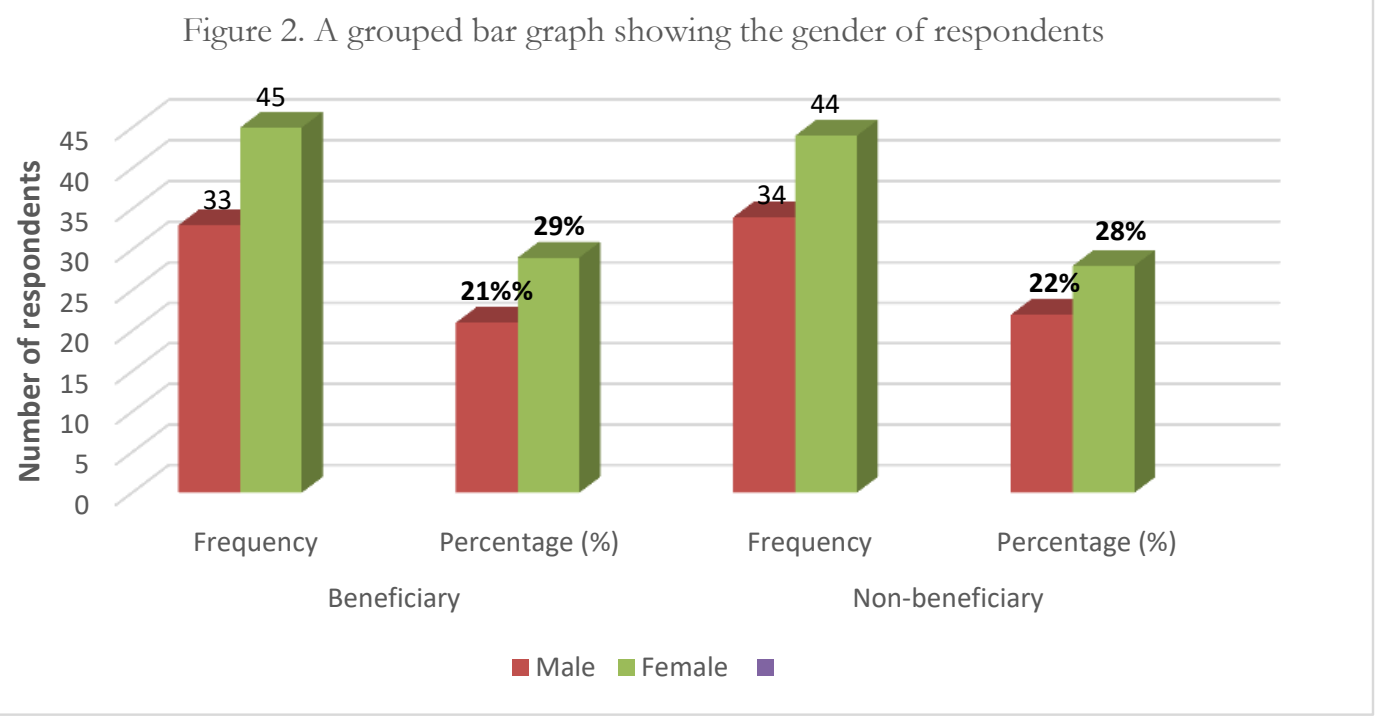

This implies that there are more females in the district than males. However, with regards to the study, Figure 2 indicates that $29 \%$ of respondents are female beneficiaries as against the male counterparts who constituted $21 \%$. This study confirms that assertion that women are more vulnerable than men and will require some form of support to reduce their vulnerabilities. Thus, CCT programs can increase women's bargaining power through the direct transfer of money that increases women's financial resources, a characteristic positively related with bargaining power (Anderson and Eswaran 2007, among others). In this case, the cash transfer has come to support such women to able to access some household assets to use for income generating activities and so improve gender relations and reduce the vulnerabilities at the household level. The claim that CCTs empower women in any given context has been a strong mechanism in gaining international support for CCTs (Shah, 2012). Giving cash directly to women is justified in the literature since women are inclined to be more responsible than men to spend the cash subsidy on their children and for the benefit of their children (Bradshaw and Viquez, 2008). This emerged the "maternal model of care" by Molyneux (2006).

\subsection{Status of CCT Beneficiary Respondents}

Conditional Cash Transfer (CCT) is a social assistance program that provides cash income to poor households 
provided they make certain investment in human capital (Abelsohn, 2011). Under the Livelihood Empowerment Against Poverty (LEAP), beneficiaries are identified as; caregivers of orphan children and vulnerable children (OVC), pregnant and lactating women, impoverished elderly, severely disabled persons, and households dependent on fishing and subsistence food crop farming (Gbedemah, et al., 2010). The category of beneficiaries of CCT in the Builsa North District was classified as indicated in Table 2. As illustrated on Table 2, the district does not make provision for pregnant and lactating women and households dependent on fishing and crop farming to benefit from CCT as postulated by Gbedemah et al. (2010). It however makes provision for direct beneficiaries such as orphan and vulnerable children (OVC), people with disabilities and the aged. Other group of people who benefit indirectly are caregivers of all categories of people.

Table 2 Status of CCT beneficiary respondents

\begin{tabular}{|l|l|l|l|l|}
\hline \multirow{2}{*}{ Status } & \multicolumn{2}{|l|}{ Direct } & Care Giver \\
\cline { 2 - 5 } & Frequency & Percentage (\%) & Frequency & Percentage (\%) \\
\hline All categories & 47 & 100 & 31 & 100 \\
\hline OVC & 14 & 29.8 & 4 & 12.9 \\
\hline PWD & 5 & 10.6 & 7 & 22.6 \\
\hline Aged & 18 & 38.3 & 11 & 35.5 \\
\hline Others & 10 & 21.3 & 9 & 29 \\
\hline
\end{tabular}

The study also found that, about $38 \%$ of direct beneficiary respondents are aged. Caregivers who receive CCT on behalf of their aged relatives also account for about $36 \%$. This indicates that the district has more beneficiaries who are aged and this can be reflected in the age distribution of respondents in Table 1 . This implies however that there were more aged female beneficiaries than aged male. Traditionally, among the Builsas, the aged (grandparents) catered for children especially their grandchildren and are instrumental at bringing them up responsibly. They were responsible for their feeding, health and education. However, the aged dominating respondents for cash income in this study implies that household income from CCT will be used judiciously for the upkeep of children and other family members. It is in the light of this that, Duflo (2003) finds that cash transfers to grandmothers have significant impact on the health status of grandchildren. Table 2 again indicates that about $52 \%$ of respondents ( $23 \%$ for direct and $29 \%$ of caregivers) are beneficiaries other than the categories listed in the table. This included widows, divorcees, single parents, traditional leaders who were found rather productive, among others who, according to the National Social Protection Strategy for Ghana (2007), were not classified as beneficiaries.

\subsection{Sources and Levels of Satisfaction of Respondents}

Income of a person plays an important role in shaping the economic conditions of an individual which in turn is likely to have bearing on the responses about a problem posed to him. The study sought to investigate the income as variable and the data related to income of the respondents. It observed from that, apart from beneficiaries of CCT, professionals and those in trade related activities, other source of income was not a regular thing and one could not tell where the next income will come from. A focus group discussion with respondents, alluded to the fact that this has made them have multiple irregular sources of income. As indicated in Table 3, one could be a beneficiary of CCT but had to still do some distress sale or depend on remittances to be able to cater for his/her household needs. Most respondents are therefore unable to tell how much they earn in a month as income. By estimation, they are able to guess and with the estimation of the researcher their income levels have been computed as illustrated in Table 3. 
Table 3: Major Sources of Incomes of Respondents

\begin{tabular}{|l|l|l|l|l|}
\hline \multirow{2}{*}{ Sources } & \multicolumn{3}{|c|}{ Respondents } \\
\cline { 2 - 5 } & \multicolumn{2}{|c|}{ Beneficiaries } & \multicolumn{2}{c|}{ Non - beneficiaries } \\
\cline { 2 - 6 } & Frequency & $\begin{array}{l}\text { Percentage } \\
(\%)\end{array}$ & Frequency & $\begin{array}{l}\text { Percentage } \\
(\%)\end{array}$ \\
\hline Credit facilities & 5 & 6.4 & 23 & 29.4 \\
\hline Salary/wage/rent & 9 & 11.5 & 11 & 14.1 \\
\hline Remittances & 17 & 21.8 & 13 & 16.7 \\
\hline CCT & 78 & 100 & - & - \\
\hline Income from distress sales & 53 & 67.9 & 68 & 87.2 \\
\hline $\begin{array}{l}\text { Profit from trade and other business-related } \\
\text { activities }\end{array}$ & 23 & 29.5 & 25 & 32.1 \\
\hline NGO support & 8 & 10.3 & 10 & 12.9 \\
\hline Retirement benefits & 5 & 6.4 & 9 & 11.5 \\
\hline
\end{tabular}

\subsection{Household Distress Management}

It is observed in Table 3 that, aside CCT, income from distress sales is higher among sources of income for both beneficiaries and non-beneficiaries of CCT. In the non-beneficiary group, it is about $87 \%$ of total earned income. In the beneficiary group, the figure is low (67\%) because, CCT has come to reduce the level of shock in beneficiary household, thereby reducing the rate at which distress sale was done. However, beneficiaries still do distress sales as a coping mechanism. They sell things ranging from farm produce to cloths. The study further revealed that a distress sale was as a result of both idiosyncratic and covariate shocks. According to CEPA (2004), 80\% of households in the Builsa areas suffer from these shocks. About 6\% beneficiary respondents had retired from government work and are able to still benefit from pension and other retirement packages. Also, $10 \%$ of beneficiaries and 13\% non-beneficiaries are engaged in NGO support schemes such as food for work by the World Food Programme, CRS, World Vision and other local NGOs such as FISTRAD, Zoomlion and the Presbyterian Agricultural Cooperation to earn income (Table 3). The implication of this finding is that, with multiple sources of income, household members are able to access some household capital assets like their finances that could either be used to undertake some income generating activities or undertake some agricultural related activities that could translate into more income and improved care for household members such as improved access to education, health and nutrition, gender relation and general well-being of the household.

Despite these multi sources, about $78 \%$ of total respondents were not satisfied with their income sources, $19 \%$ were satisfied and $3 \%$ very satisfied with their income sources (Table 4 ). This could imply that though they have multiple sources of income, it is not statistically significant and the need for the CCT to be expanded to include some Non-beneficiaries and /or increase amount for beneficiaries. It is evident from Table 4 that about $77 \%$ of respondents are in the low-income level, representing about $40 \%$ for beneficiaries and $37 \%$ for nonbeneficiary respondents. Only 3\% beneficiary respondents and 4\% non-beneficiaries are in the upper class of income levels representing a total of $6 \%$ of total respondents. This implies that, though beneficiary respondents enjoy CCT, their incomes levels are inadequate to meet household need as compared to their non-beneficiaries' counterparts.

Table 4: Level of Satisfaction of Income Sources

\begin{tabular}{|l|l|l|l|l|}
\hline \multirow{2}{*}{$\begin{array}{l}\text { Income } \\
\text { levels }\end{array}$} & \multicolumn{4}{|c|}{ Respondents } \\
\cline { 2 - 5 } & \multicolumn{3}{|c|}{ Beneficiaries } & \multicolumn{2}{c|}{ Non -Beneficiaries } \\
\cline { 2 - 5 } & Frequency & Percentage (\%) & Frequency & Percentage (\%) \\
\hline All levels & 78 & 50 & 78 & 50 \\
\hline Low & 63 & 40.4 & 57 & 36.5 \\
\hline Medium & 11 & 7.1 & 15 & 9.6 \\
\hline High & 4 & 2.6 & 6 & 3.8 \\
\hline
\end{tabular}

It could also be argued that non-beneficiaries are relatively in higher in income levels because they are involved in more trade related activities and record a higher number of professionals as indicated in Table 3 . It 
could equally be argued that apart from distress sales, non-beneficiary respondents earn more income from trade related activities and salary/wage/rent than beneficiary respondents.

\subsection{LEAP Cash Income and Household Economic/Financial Assets}

According to DFID (1999), financial capital refers to the financial resources that people use to achieve their livelihood objectives. It includes credit, savings and remittances. The provision of these financial resources helps to develop the financial capital of the household. The study that access to credit, CCT, savings/loans, remittances, salaries and pensions are the financial capital base of respondents (Table 5).

Table 5: Beneficiaries Economic/Financial Capital Assets

\begin{tabular}{l|ll|}
\hline Asset & Frequency & Percentage (\%) \\
\hline Access to credit & 5 & 6.4 \\
Benefits from CCT & 78 & 100 \\
Savings/insurance & 11 & 14.1 \\
Remittances & 17 & 21.8 \\
Salaries/wages/rent & 9 & 11.5 \\
Pension benefits & 5 & 6.4 \\
\hline
\end{tabular}

As indicated from Table 5, the major source of financial asset to beneficiary respondents is the conditional cash transfer (CCT), with all the beneficiary respondents benefiting either directly or indirectly from CCT. The over dependence on cash income as their key assets often does not mean that their assets must be converted into cash in order to be used for consumption. Also, while credit may be a key asset for the household members, many households and individuals are unable to access credit through formal market, or even through more expensive informal markets. About $6.4 \%$ and $30 \%$ of beneficiary and non-beneficiary respondents respectively have access to credit from some financial institutions and micro finance agencies. For the household to be economically strengthened, its members must have access to various capital assets. However, the difficulty with most households is the inability to access them. Members of the household are unable because they are either aged and weak and therefore unhealthy, they are incapacitated or have no support system available to access these assets. The few members who are physically strong and healthy and are able to acquire these assets, unfortunately, are also confronted with challenges such as will power to access these assets.

The study also revealed that though they are a myriad of capital assets in the district, beneficiaries are unable to access them fully so as to convert them to some productive usage. This explains why vast agricultural lands for farming are unable to yield much produce because they are not fertile enough. Beneficiary members of CCT as a household safety net still live in situations of extreme vulnerabilities acquiring fewer assets which are unable to bring them out of their poverty situations. This explains why, in the study, respondents agreed that, there is the need for adequate support system(s) to households to be able to fully access various economic assets to secure their household economy.

\subsection{Influence of LEAP Cash Transfers on Household Economic Outcomes of Beneficiaries}

The study revealed that generally, the small but predictable cash income has improved wellbeing of household members and reduced vulnerability, though, this improvement is not statistically significant. The study revealed that about $67 \%$ of respondents agreed that lifestyles of beneficiaries have improved. This implies that, they are able to eat at least, twice a day, buy agricultural inputs, secure food for the lean season, and educate their children. It was revealed that all beneficiaries of CCT are registered with the National Health Insurance Scheme (NHIS). This has enabled them cater for their health needs and also contributed towards the provision for health for other members of the household.

About $26 \%$ of respondents also argued that, there is no change in beneficiaries' lifestyles and that;

"One could not see any change in beneficiaries since they started benefiting from the money", FGD

"how much is that money that one can just change like that"? FGD

However, about $7 \%$ of respondents thought that beneficiaries are worst off benefiting from the cash income. This implies that, rather than using cash to support the household, they abuse the use of it by engaging in alcoholism, womanising, and smoking. This invariably is not the purpose of the CCT. Also, in trying to compare lifestyles of beneficiaries to non-beneficiaries in relations to their household economic outcomes, it was revealed that about $37 \%$ of beneficiary respondents have a more reliable and regular source of income than nonbeneficiaries. This implies that, despite the fact that sometimes payment of cash delays and given the periodic payments made to beneficiaries they still consider it regular and reliable. Beneficiaries mentioned that, hitherto to the introduction of the cash program, most of them found it difficult to make a cedi a day for a living and so were 
very glad to have a reliable source of cash for their survival. Comparing beneficiaries to non-beneficiaries, they said, though most non-beneficiaries are traders, it was not all the time they are able to make sales and that most businesses in the district were seasonal.

On whether beneficiaries are able to use cash judiciously or not as working capital as also indicated in Table 6 , about $42.9 \%$ respondents disagreed that, beneficiaries were not physically and mentally able to use additional funds as working capital. This implies beneficiaries do not undertake businesses and the few who do will say the amount is not so much to use as working capital. They would rather invest the funds into agricultural production and some human capital development issues such as feeding in the household, providing educational and health needs to children and other family members and other distress expenditures in the household. About $51.9 \%$ strongly agree to this assertion that beneficiaries would prefer to invest cash income on human capital. However, $78.1 \%$ disagreed that beneficiaries in the household are able to have access to and control of sufficient capital such as land, labour, credit and social networks. Despite the fact that they invest their cash income into farming, they do on a smaller scale and usually on household's farms without any much influence from their receipt of cash income. It was also revealed that, $34 \%$ of respondents disagreed that beneficiaries are not intrinsically risk averse and that they are open to taking risk with cash transfer given the opportunity.

Table 6: Comparing outcomes of Beneficiaries and Non-beneficiaries

\begin{tabular}{|c|c|c|c|}
\hline Statement & Level of agreement & Frequency & Percentage \\
\hline \multirow{5}{*}{$\begin{array}{l}\text { Beneficiaries of cash income have a more } \\
\text { reliable and regular source of income than } \\
\text { non-beneficiaries }\end{array}$} & 1 & 10 & 6.4 \\
\hline & 2 & 5 & 3.2 \\
\hline & 3 & 46 & 29.5 \\
\hline & 4 & 38 & 24.4 \\
\hline & 5 & 57 & 36.5 \\
\hline Total & - & 156 & 100 \\
\hline \multirow{5}{*}{$\begin{array}{l}\text { Beneficiaries are physically and mentally } \\
\text { able to use additional funds as working } \\
\text { capital }\end{array}$} & 1 & 19 & 12.1 \\
\hline & 2 & 67 & 42.9 \\
\hline & 3 & 25 & 16.0 \\
\hline & 4 & 28 & 17.9 \\
\hline & 5 & 17 & 10.9 \\
\hline Total & - & 156 & 100 \\
\hline \multirow{5}{*}{$\begin{array}{l}\text { Beneficiaries household are more likely to } \\
\text { invest in human capital (e.g food, health and } \\
\text { education) than non-beneficiaries }\end{array}$} & 1 & 5 & 3.2 \\
\hline & 2 & 11 & 7.1 \\
\hline & 3 & 14 & 9.0 \\
\hline & 4 & 45 & 28.8 \\
\hline & 5 & 81 & 51.9 \\
\hline Total & - & 156 & 100 \\
\hline \multirow{5}{*}{$\begin{array}{l}\text { Beneficiary households have access to and } \\
\text { control over sufficient capital (land, labour, } \\
\text { credit, social networks, productive assets) } \\
\text { than non-beneficiaries }\end{array}$} & 1 & 38 & 24.4 \\
\hline & 2 & 75 & 48.1 \\
\hline & 3 & 5 & 3.2 \\
\hline & 4 & 9 & 5.8 \\
\hline & 5 & 29 & 18.5 \\
\hline Total & - & 156 & 100 \\
\hline \multirow{5}{*}{$\begin{array}{l}\text { Beneficiary households are not intrinsically } \\
\text { risk averse than Non-beneficiaries }\end{array}$} & 1 & 49 & 31.4 \\
\hline & 2 & 53 & 34.0 \\
\hline & 3 & 10 & 6.4 \\
\hline & 4 & 32 & 20.5 \\
\hline & 5 & 12 & 7.7 \\
\hline Total & - & 156 & 100 \\
\hline
\end{tabular}




\begin{tabular}{l|ll|l|}
\multicolumn{4}{c}{ Table 7: Enhance Beneficiary Ability to Access Certain Resources } \\
\hline Statement & Response & Frequency & Percentage \\
\hline Ability to make friends & Yes & 83 & 53.2 \\
Ability to work with other people & No & 79 & 50.6 \\
Ability to access information & Yes & 81 & 51.9 \\
Ability to access processing skills & No & 98 & 62.8 \\
Ability to access processing equipment & No & 103 & 66 \\
Ability to access some level of credit for household & No & 117 & 75 \\
Ability to improve nutrition and health & yes & 153 & 98 \\
Ability to accumulate enough savings to survive low cash flow & yes & 138 & 88.5 \\
season & & & \\
Ability to access community markets & yes & 99 & 63.5 \\
Ability to manage scarce resources available for business & no & 149 & 95.5 \\
Ability to live in better homes & no & 132 & 84.6 \\
\hline
\end{tabular}

From Table 7, it can be observed that about $53 \%$ respondents agreed to the fact that cash income has enhanced beneficiaries' ability to make friends. This stem from the fact that, cash disbursement is usually done in a community forum, where all beneficiaries are gathered with the help of the Community LEAP Implementation Committee (CLIC), to receive payments. Beneficiaries in this gathering interact and make new friends among themselves or with the team from the Department of Social Welfare. From tis interaction among themselves they are able to support each other either in kind or in cash. About 51.9\% of respondents also agreed that, coming together to receive payments will expose beneficiaries to some vital information about their community and beyond. Most NGOs, government agencies/institutions like the Ministry of Health and researchers for instance, have identified such gatherings for their community fora and durbars. Such organisations work with the Department of Social Development to identify payments days and they go there to either run sensitisation programmes or create awareness about social events. Most beneficiaries have no access to some formal credit facilities. However, about $75 \%$ of respondents said the only credit they get is the CCT. This credit has helped them to improve their nutritional and health status in the households. About $98 \%$ agreed to this fact and added that all beneficiaries have access to the National Health Insurance Scheme since it's an integral part of the conditions of the CCT. This has helped them taken care of their health and improved nutrition. Also, the table further revealed that about $50.6 \%$ of respondents said they are not able to work together for a common goal and that each beneficiary is responsible for the usage of his/her cash received. In addition to that about $84.6 \%$ of respondents do not live in better homes. They said the money received is not adequate to put up decent homes. Most respondents still live in mud houses with or without gates.

\section{Conclusion}

Although small and predictable, LEAP cash income has influenced household economic assets, as it has enhanced ability of beneficiaries to participate in social functions, access education/ literacy as human capital asset, and access vast agricultural lands to undertake crop farming activities. The conditional cash transfer is a wellintentioned social intervention program that has played a pivotal role at strengthening the economic and social fortunes of majority of vulnerable households in the Builsa north district. The program has enabled most vulnerable households have access to some household economic assets that have been used to generate some economic outcomes of the households, such as facilitating their agriculture and related activities and the provision of health and nutritional needs for members of the household. It is recommended to the implementing ministry, the Ministry of Gender and its subsidiary agencies at the District level to educate beneficiaries of the CCT to believe more in their individual efforts with little support such as the cash transfer. With this, the cash transfer program (LEAP) would be able to achieve its targeted objectives by intensifying their educational and training activities for beneficiaries on the operations and benefits of the cash payments and how it can be used judiciously by beneficiaries to strengthen their households. The FAO and UNESCO have recognized education and training as important weapons in the fight against rural poverty.

\section{References}

Abelsohn J. (2011). A philosophical framework for conditional cash transfer. CMC Theses, paper 217. Retrieved from http://scholarship.claremont.edu/cmc theses/217

Adato, M.\& Hodinott, J. (2010). Conditional cash transfer in Latin America, 2010 International Food Policy Research Institute, John Hopkins University Press. Baltimore.

Adato, M., Coady, D., \& Ruel, M. (2000). An operations evaluation of PROGRESA from the perspective of beneficiaries, promotoras, school directors, and health staff. Final report to PROGRESA, Government of Mexico. Washington, DC: International Food Policy Research Institute.

Adjei, P. O., Aboagye, D., \& Yeboah, T. (2012). Extreme poverty and vulnerability experiences on urban highways 
in Ghana: Assessing social protection policy responses. Educational Research 3(5), 436-446.

Alkire, S., Conconi, A., \& Seth, S. (2014). Multidimensional Poverty Index 2014: Brief methodological note and results. Oxford: Oxford Poverty and Human Development Initiative, University of Oxford.

Anderson, S., \& Eswaran M., (2009). What determines female autonomy? Evidence from Bangladesh. Journal of Development Economics, 90(2), 179-191.

Behrman, J. R., Gallardo-Garcia, J., \&Parker, S. W., (2012). Are Conditional Cash transfers effective in urban areas? Evidence from Mexico. Journal of Education Economics, Vol. 20, No. 3.

Booth, D., Holland, J., \& Hentschel, J., (1998). Participation and combined methods in African poverty assessment: renewing the agenda. London: DFID.

Bradshaw, S. \& Viquez, A. (2008). Women beneficiaries or women bearing the cost: A gendered analysis of the Red de Proteccion Social in Nicaragua. Development and Change, 39:5, $23-44$.

Builsa District Assembly (2004), District Human Development Report, 2004.

Builsa District Assembly (2010) District Medium -Term Development Plan (2010-2013).

Builsa North District Assembly (2012), District Annual Progress Report, 2012.

Case A., \& Deaton, A. (1998). A large cash transfers to the elderly in South Africa. Economic Journal, 108(450), 1330-1361.

Centre for Policy Analysis. (2004). Report on socio - economic survey in the Bulsa district in 2004.

Chandy L., \& Gertz G. (2011). Poverty in numbers: The changing state of global poverty from 2005 to 2015. Policy Brief 2011.1. Washington D.C.: The Brookings Institute.

Daily Graphic. (2012). 68,000 Households Benefit From LEAP. Retrieved on April 20, 2012 from http://www.ghana.gov.gh/index.php/news/features/11651--68000-households- benefit-from-leap

Daidon, S. \& Davis, B. (2013). The impact of cash transfer on productive activities and labour supply: The case of LEAP programme in Ghana.CSAE Conference Rome.

Department for International Development (2011). Cash transfers. (Evidence Paper). London: DFID.

Department for International Development (2011), Business Case: Millennium Village in Northern Ghana. London: DFID

Department for International Development. (1999), Learning opportunities for all: A policy framework for education. London: DFID

Duflo, E. (2003). Grandmothers and granddaughters: Oldage pensions and intrahousehold allocation in South Africa. World Bank Economic Review, 17(1), 1-25.

Farrington, J., Slater, R. \& Holmes, R, (2004). Social protection and pro-poor agricultural growth: What scope for synergies? Retrieved from http:/www.odi.org.uk/resources/specialist/natural-resourceperspectives/91social- protection-pro-poor-agricultural-growth.pdf

Fiszbein, A., Schady, N. \&, Ferreira, F. (2009). Conditional cash transfers: Reducing present and future Poverty.Washington, D.C. The World Bank

Food and Agriculture Organization. (2014). The State of Food Insecurity in the World 2014: Strengthening enabling environment for food security and nutrition. Rome: FAO retrieved from http://www.fao.org/publications/sofi/2014/en/

Gbedemah, C., Jones, N., \& Pereznieto, P. (2010). Gendered risks, poverty and vulnerability in Ghana: Is the LEAP cash transfer programme making a difference? London: Overseas Development Institute (ODI).

Ghana. National Development Planning Commission. (2004), District human development report for Atwima, Builsa and Tema Districts. Accra. NDPC.

Ghana Statistical Service. (2013). Non-monetary poverty in Ghana: 2010 Population and Housing Census Report. Accra: Ghana Statistical Service.

Ghana Statistical Service. (2008). Ghana living standards survey: Report of the fifth round. Accra: Ghana Statistical Service.

Ghana. Ministry of Manpower, Youth and Employment (2007). National Social Protection Strategy, Accra: MMYE

Holmes, R., \& Barrientos, A. (2009). Child poverty: A role for cash transfers in West and Central Africa? Briefing Paper: UNICEF and London: UNICEF/Overseas Development Institute (ODI).

Jones, N., Ahadzie, W., \& Doh, D. (2009). Social protection to tackle child poverty in Ghana. Briefing Paper: London: UNICEF/Overseas Development Institute (ODI).

Kumado, K. \& A.F. Gockel, A.F. (2003). A study on social security in Ghana. Working paper, February 2003. University of Ghana, Legon

Mertens, D.M. (2003). Mixed methods and the politics of human research: the transformative-emancipator perspective. In A. Thashakkori and C. Teddlie (Eds), Handbook on mixed methods in the behavioural and social sciences. Thousand Oaks, CA: Sage.

Molyneux, M. (2006). Mothers at the service of the new poverty agenda. Social Policy and Administration, 40:4. 425-449. 
Oxford Policy Management. (2013). Qualitative research and analyses of the economic impacts of cash transfer programmes in sub-Saharan Africa: Ghana Case Study, mimeo, OPM.

Sachs, J. C. (2005). The end of poverty. London: Penguin Books.

Schady, N. \& Rosero, J. (2007), Are cash transfers made to women spent like other sources of income?The World Bank, Policy Research Working Paper Series 4282.

Schultz, T.P. (2001). School subsidies for the poor: Evaluating a Mexican strategy for reducing poverty. Washington, D.C.: International Food Policy Research Institute.

Schultz, T.P. (2004). School subsidies for the poor: Evaluating the Mexican PROGRESA poverty program. Journal of Development Economics, 74(1), 199-250.

Schubert, B. (2008). Protecting the poorest with cash transfers in low income countries. In A. Barrientos, D.

Schubert, B., \& Slater, R. (2006). Social cash transfers in low-income African countries: conditional or unconditional? Development Policy Review 24(5), 571-578.

Slater, R. (2011). Cash transfers, social protection and poverty reduction. International Journal of Social Welfare, 20(3), 250-259

Twumasi, P.A. (2001). Social research in rural communities. Accra: Ghana Universities Press.

World Bank. (2008). Cuál es el camino a seguir para fomentar políticas públicas más amplias y sostenibles?" Proceedings of the Workshop of the CCT Community of Practitioners, Cuernavaca, Mexico, January 15-18.

World Food Programme Report (2013) retrieved fromwww.wfp.org/countries/ghana/overview

Yakubu, A.R. (2012), Economic and Socio-cultural impediments to Girls education: Builsa District of Upper East Region of Ghana. MPhil Thesis, University for Development. Unpublished. 